
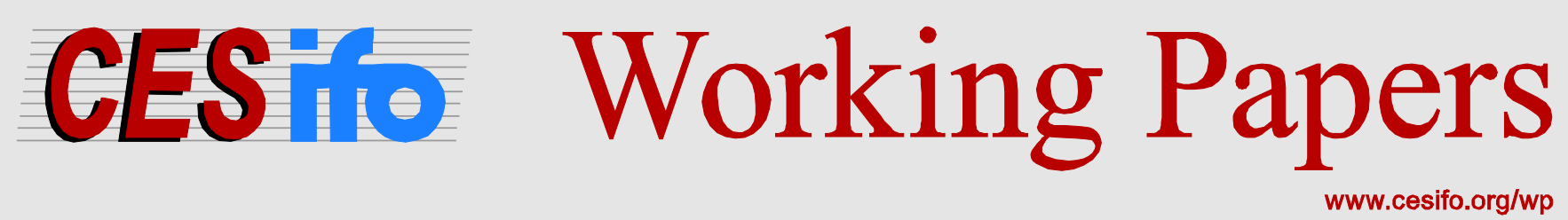

\title{
What Do Immigrants Value Most About Switzerland? Evidence of the Relative Importance of Income Taxes
}

\author{
Mario Morger \\ CESIFO WORKING PAPER NO. 4134 \\ CATEGORY 1: PUBLIC FinANCE \\ FEBRUARY 2013 \\ An electronic version of the paper may be downloaded \\ - from the SSRN website: \\ - from the RePEc website: \\ - from the CESifo website: \\ WWW.SSRN.com \\ www.RePEc.org \\ www.CESifo-group.org/wp
}

\section{CESifo}




\title{
What Do Immigrants Value Most About Switzerland? Evidence of the Relative Importance of Income Taxes
}

\begin{abstract}
This study investigates whether migrants, once they have decided to move to Switzerland, prefer to settle in municipalities that feature low income taxes. In line with the existing literature, results from cluster-specific count data models indicate that income taxes are a significant pull factor for international migration decisions. The same is true with respect to intra-national migration. However, dominance analysis suggests that the relative impact of taxes compared to other locational factors is rather low. Urbanity characteristics, labormarket, and network effects are by far the most important factors to influence the choice of destination municipality.
\end{abstract}

JEL-Code: H240, H730, J610, R230.

Keywords: migration, tax competition, dominance analysis, relative importance.

\author{
Mario Morger \\ Federal Tax Administration \\ Division Analysis and Data \\ Eigerstrasse 65 \\ 3003 Berne \\ Switzerland \\ mario.morger@estv.admin.ch
}

February 12, 2012

I am grateful to Martin Daepp, Bruno Jeitziner, Alowin Moes, Raphaël Parchet, Rudi Peters, Peter Schwarz, and the participants of the 1st CEMIR Conference on international migration at CESifo for their helpful discussion and comments. 
Social, technical, and economic forces have led to greater erosion of political barriers. As a result, the intra- and international mobility of households has steadily increased and, with it, competition among enterprises with respect to highly skilled labor. Traditional theory dating back to Hicks (1932) argues that migration is driven by differences in wages between the source and destination countries. Empirical studies more or less find evidence for the validity of this assertion (see the discussion in Hatton and Williamson 2002), but opinions on its relative importance compared to other factors are mixed. For example, Zavodny (1999) and Haug (2008) conclude that network effects - i.e. the presence of earlier immigrants - are more important. If the net wage matters in making migration decisions, income taxes should matter too, as they drive a wedge between gross and net wages.

Contrary to traditional economic theory, the public finance literature sees fiscal policy as a central migration driver. Tiebout (1956) understands mobility to be a result of well-informed households trying to maximize their utility by migrating to a community that offers the best service-tax package. According to this so-called voting with one's feet mechanism, households with strong preferences for public goods settle in high-tax communities, whereas households with little preference for public goods will move to low-tax communities.

The volume of tax-induced migration literature is vast, if one considers intra-national mobility (for a review, see Dowding et al. 1994). With regard to international migration, however, the tax literature is still nascent. Only recently and with the availability of new international migration databases, some empirical studies have been undertaken (Wagner 2000; Pirttilä 2004; Pedersen et al. 2008; Egger and Radulescu 2009; Geis et al. 2008; Nowotny 2011; Kleven et al. 2010 and 2011). Most studies conclude that regional tax burden negatively impacts the choice of residence. However, there persists great incertitude vis-à-vis the relative importance of taxes, compared to other factors.

This study looks to contribute to the literature by rectifying this lack of certitude. First, it will investigate whether immigrants, having decided to migrate into Switzerland, prefer to settle in municipalities with a low income tax burden. Second, the relative importance of taxes compared to other pull factors will be deduced with the help of dominance analysis (see Budescu 1993; Azen and Traxel 2009). As Swiss municipalities have substantial tax authority, income taxes can vary considerably, even between relatively nearby regions. These circumstances allow us to separate the impact of taxes from those of other regional aspects that influence migration decisions. Therefore, Switzerland serves as a good candidate for a 
model by which to investigate the potential influence of tax competition on international migration. The results from different cluster-specific count data models show that taxes do indeed significantly matter with respect to migration; however, the relative impact is rather low. The effects of urbanity characteristics, the labor-market, and the network are by far the most important factors that influence the choice of destination municipality.

This paper is organized as follows. Section 2 reviews the existing literature on tax-induced international migration. Sections 3 and 4 present the empirical model and dominance analysis, respectively, and section 5 provides a short description of personal income taxation in Switzerland. In section 6, the database is described. Section 7 discusses the estimation results, while section 8 provides the concluding remarks.

\section{Literature on tax induced international migration}

The study of Dowding et al. (1994) is a valuable resource with regard to the 'voting with one's feet' phenomenon. With the help of a survey of literature from the United Kingdom, the United States, and Canada, the authors draw three main conclusions which are important for this study: First, intra-national migration can be at least partially explained by regional differences in taxes and welfare generosity. Second, public-goods provision like health and educational services also matter with regard to their decision on where to live. Third, affluent individuals 'team up' in order to prevent resource redistribution that favors the poor. Further, Dowding et al. (1994) determine that the service-tax mix is a pull rather than a push factor for migration. ${ }^{1}$

With respect to Switzerland, early studies investigating the impact of income tax competition on within-Switzerland migration include those of Kirchgässner and Pommerehne (1996) and Feld and Kirchgässner (2001). These studies examine the potential outcomes of migration while estimating the impact of local income tax differentials on regional income distribution, and both studies do so with the help of cross-sectional, aggregated data. Both studies conclude that income distribution can be partially explained by fiscal factors. By using panel data, Schaltegger et al. (2011) confirm these results for the Zurich metropolitan area. Schmidheiny (2006), Liebig and Sousa-Poza (2006), and Liebig et al. (2007) directly investigate the connection between migration decisions and local income taxes, using individual-level data.

\footnotetext{
${ }^{1}$ Pull factors determine the emigration decision, whereas push factors influence the decision of where to migrate.
} 
Schmidheiny (2006) and Liebig et al. (2007) find evidence that highly qualified and affluent households are more willing to migrate in response to tax incentives than the average population; however, Liebig and Sousa-Poza (2006) find income taxes to have no impact on intra-national migration decisions.

In summary, most international and Swiss studies show some consensus about the relevance of the sorting mechanism proposed by Tiebout (1956).

Concerning international mobility, there is only scant evidence of the influence of differences in income tax burden. This is due to the fact that no micro-level database of international migration exists. As a consequence, authors need to develop their own databases (e.g. Wagner 2000; Geis et al. 2008; Kleven et al. 2010; Nowotny 2011), use aggregated Organisation for Economic Co-operation and Development (OECD) migration flow data (Pirttilä 2004; Pedersen et al. 2008; Egger and Radulescu 2009), or use other nonmigration-specific databases (Kleven et al. 2011). These studies are discussed below in greater detail.

Using data of a Canadian and a US household survey, Wagner (2000) analyses whether differences in income and tax burden can explain the 'brain drain' from Canada to the United States in the 1990s. As a first step, Wagner simulates the hypothetical income and tax burden of the Canadian households, if they had resided in the other country. As a second step, the author analyses how socio-demographic factors influence the place of residence of Canadians, by applying a probit model. Wagner finds that tax differentials between Canada and the United States do matter - statistically significantly so. The effective tax savings of emigrated households are higher compared to the hypothetical tax savings of nonmigrants. However, the relative impact of taxes on the decision of where to live is rather low: if tax rates were identical in both countries during the 1990s, the emigration rate from Canada would have been reduced by only $10 \%$.

Geis et al. (2008) merge micro-level datasets from France, Germany, the United Kingdom, and the United States, in order to explain the stock of migrants therein. With the help of multinomial logit regression, the authors find the effects of the tax wedge (according to the definitions of the OECD) to be statistically significant, and that it has a negative impact on the number of immigrants, irrespective of whether those immigrants are low or high-skilled. Also, a generous pension benefit system negatively influences immigration decisions. On the other hand, good education and healthcare systems appear to have a positive impact.

Nowotny (2011) applies an approach comparable to that of Geis et al. The author studies the factors that determine the stock of migrants for 158 regions within 15 European Union (EU) 
countries. With the help of conditional logit, Nowotny finds the effect of the tax wedge to be statistically significant, and that income tax progression negatively influences the attractiveness of immigration.

Pirttilä (2004) investigates the factors that prompt highly educated Finnish inhabitants to migrate to one of 20 OECD countries. By applying generalized method of moments (GMM) panel regression, Pirttilä concludes that the tax burden did not significantly influence immigration decisions during the 1990s. However, in accordance with traditional theory, outmigration seems to be more pronounced in countries that are in proximity to the host country, have high economic growth rates, and are affluent.

Pedersen et al. (2008) examined the factors that potentially explain migration rates among 27 OECD countries between 1990 and 2000, from 129 countries of origin. Their linear panel regression model includes macro-level data, and 'tax burden' is defined as centralgovernment tax earnings as a share of gross domestic product (GDP). For only some empirical specifications, the authors find evidence that taxes do influence the immigration rate; they also do not find clear evidence that immigrants from affluent countries are more tax-sensitive than those from poor countries.

Egger and Radulescu (2009) use cross-sectional data from 49 countries, from the year 2002. With the help of Poisson, Negbin, and Heckman selection models, the authors find that the average tax burden on labor (as defined by the OECD taxing wages approach) has a significant impact on the bilateral flows of skilled migrants and the stock of expatriates. The same is true with respect to tax progressivity: net immigration of skilled labor is higher into countries where progressivity is relatively low, all other things being equal.

Kleven et al. (2010) analyzed the tax-induced migration of top football players in Europe. Following the liberalization of the European football market in 1995, the mobility of footballers substantially increased. The authors constructed a large panel dataset of football players from 14 European countries, and by applying multinomial logit and random parameters logit, they find robust empirical evidence that the tax rate significantly influences locational decisions. Their results suggest that low taxes will attract top footballers. At the same time, low taxes push out subtop foreign footballers, as demand for footballers is relatively inelastic.

Kleven et al. (2011) evaluated a preferential tax regime introduced in the 1990s in Denmark for highly paid migrants (i.e. those above the 99th income decile). The authors test the hypothesis that following the introduction of the regime, the immigration of these highly 
qualified workers substantially increased. Their difference-in-difference estimates show that the ratio of eligible workers to slightly lower-paid ineligible workers had doubled, resulting in elasticity of migration with respect to a net-of-tax ratio of around 1.5.

In summary, a review of the literature leads one to conclude that taxes do matter with regard to international migration. However, some studies face methodological problems, and this calls into question the robustness of some results. First, regressing the stock of migrants on the tax burden of a specific year (as Wagner 2000, Geis et al. 2008, and Nowotny 2011 do) does not ensure the validity of analyzing causality between tax rates and migration. It is impossible for actual tax rates to have influenced past migration flows (and thus the actual numbers of immigrants); therefore, if in these studies statistical significance is found, it must be due to some indirect mechanism. On one hand, it could be because taxes in the respective countries do not vary greatly from year to year; the other possibility is that some omitted variables correlate with the tax variable, and so the estimated tax-coefficients are biased.

Second, the global tax revenue of a given country serves as a very rough estimate of the individual tax burden placed on households, which neither maps the general burden that falls onto labor nor the individual tax burden, which varies depending on family structure and working conditions. For this reason, it is not surprising that the results of Pedersen et al. (2008) provide no clear picture of the influence of taxes on immigration flows.

Regarding the other studies (i.e. Egger and Radulescu 2009; Pirttilä 2004; Kleven et al. 2010 and 2011), all but those of Pirttilä (2004) conclude that higher taxes are accompanied by lower migration. This coincidence of evidence is remarkable, as these studies differ substantially in terms of their methodological approaches and the databases used. This indicates that income taxes indeed constitute a factor that influences the decision of where to live.

Nonetheless, further research is needed. One reason is methodological. Regression-based analysis has the problems of omitted-variable bias and multicollinearity, both of which occur when estimating regression coefficients (or elasticities). Specifically, the tax burden correlates strongly with the size of the public sector. Empirical studies show that public goods such as unemployment insurance and qualitatively good health and education systems are valued by migrants. This leads to a dilemma: if one figures the impact of taxes into migration, one can either control for public goods provision, which leads to multicollinearity problems, or one can exclude public goods control variables, which leads to omitted-variable bias problems and 
to a tax coefficient that is potentially downward-biased. This study will address these problems and offer a solution through cluster-specific count data analysis.

With respect to political aspects, there is a need for further research, because little is known about the relative importance of taxes compared to other factors that influence the attractiveness of a country. However, knowing its relative relevance is important in developing regional economic policy, as it is part of an ongoing debate on how fiscally attractive countries must be in order to realize a 'brain gain' rather than a 'brain drain', as well as the monetary costs at which such attractiveness can be achieved.

\section{The utility maximizing model}

Assume a household $i$ that has decided to migrate to Switzerland. According to its preferences (e.g. locational factors like proximity to employer, or nearby public-goods provision) it wants to settle in one of a set of municipalities $m=1, \ldots, M$. The household will choose the municipality $m$ that maximizes its utility $U_{i}$ :

$$
U_{i m}>U_{i k} \forall k, k \neq m \text {. }
$$

Assuming that $U_{i m}$ can be represented by the additive random utility model, we can split $U_{i m}$ into a deterministic component of the utility function, $V_{i m}$, and a stochastic error term, $\varepsilon_{i m}$ :

$$
U_{i m}=V_{i m}+\varepsilon_{i m}=x_{i m}^{\prime} \beta+\varepsilon_{i m},
$$

where the vector $\boldsymbol{x}_{i m}^{\prime}$ includes pull factors that are relevant to locational choice and $\beta$ is a vector of unknown importance weights, which we assume to be identical across individuals. If the stochastic error component, $\varepsilon_{i m}$, has a distribution that is an extreme value type- 1 , then the probability $p_{i m}$ that the household will choose to live in municipality $m$ is given by:

$$
p_{i m}=\frac{\exp \left(x^{\prime}{ }_{i m} \beta\right)}{\sum_{m=1}^{M} \exp \left(x^{\prime}{ }_{i m} \beta\right)},
$$

where (3) is the conditional logit model. Guimarães et al. (2003) show that the log likelihood function from the conditional logit model,

$$
\log L=\sum_{m=1}^{M} n_{m} \log p_{m}
$$


is equivalent to the log likelihood function of the Poisson model (with the only difference being that the log likelihood of the two differ in terms of a constant). $n_{m}$ is the number of immigrants who move to municipality $m$, and it is Poisson-distributed. In such a case, the ARUM can be represented as follows (Guimarães et al. 2003; Brülhart et al. 2012):

$$
\begin{aligned}
E\left(n_{m} \mid \boldsymbol{x}_{\boldsymbol{m}}\right) & =\mu_{m}=\exp \left(\alpha+\boldsymbol{x}_{m}^{\prime} \beta\right) \\
n_{m} & \sim \text { Poisson }\left[\mu_{m}\right],
\end{aligned}
$$

where $\mu_{m}$ is the expected mean of the number of immigrants into municipality $m$ and $\alpha$ is a constant. A key characteristic of the Poisson process is its equidispersion, which implies that the variance and mean are identical: $\left(n_{m}\right)=\operatorname{Var}\left(n_{m}\right)=\mu_{m}$. Relating to most datagenerating processes, this is surely a very restrictive assumption; we will return to this point later.

In the empirical migration literature, several authors work with Poisson regression (e.g. Flowerdew and Aitkin 1982; Lovett et al. 1985; Börsch-Supan 1990; Shen 1999). Bessey (2007) applies a fixed-effects Poisson regression to investigate the determinants of student migration. Concerning the aforementioned literature on fiscally induced international migration, Egger and Radulescu (2009) apply Poisson, Negative Binomial and Heckman Selection regression.

Returning to equation (5), we assume that households that decide to move to Switzerland can be grouped according to their various tastes. We do not directly observe these different tastes $c=1, \ldots, C$, but we see the results thereof, as people with comparable preferences settle in comparable or identical agglomerations. Specifically, we assume that people vote with their feet, but that there is some extended form of 'voting' where not only fiscal variables matter but also other factors like recreational possibilities, quality of life, and so on. Besides this spatial 'preference-clustering', it is plausible to assume immigrants cluster into agglomerations according to their profession (due to industrial clustering). For example, pharmaceutical and chemical researchers will most likely migrate to the Basel metropolitan area; bankers to the Zurich or Geneva metropolitan regions; public service to Bern; and retirees probably to the Swiss mountains. Given these considerations, we assume that there exists some regional clustering of immigrants into $c=1, \ldots, C$ agglomerations, where every municipality $m$ is a subset of one of the agglomerations. Then, we rewrite equation (5) as follows:

$$
E\left(n_{m c} \mid \boldsymbol{x}_{\boldsymbol{m c}}\right)=\mu_{m c}=\exp \left(x_{m c}^{\prime} \beta+\alpha_{c}\right) .
$$


This leads to the so-called Poisson model with cluster-specific fixed effects $(P F E){ }^{2}$ This model has two advantages compared to simple Poisson regression. First, it allows us to account for any non-observable data with fixed effects at the clustering level. Then, the coefficients $\beta$ can be consistently estimated, even if there is some correlation between the fixed effects and the other regressors. With this specification, the problem of omitted-variable bias mentioned above can be mitigated. Second, Wooldridge (1999) proposes an asymptotic variance estimator, which fully guarantees robustness to distributional misspecification, as well as within-group correlation. This is a strong argument in favor of the PFE, because overdispersion is a considerable problem inherent in Poisson regression; the only constraint with regard to consistency is that the conditional mean is well-specified. A drawback of the PFE model is that it is less efficient than the random-effects Poisson model (PRE) if the clusters are purely exogenous. It is, however, not known if the PRE is robust when distributional assumptions are violated (Wooldridge 2006).

The aim of the current study is to estimate a migration model using equation (6). To test whether the model performs well, we complement the PFE analysis with the negative binomial regression model (negbin; type 2) and the zero-inflated negbin model. Specifically, we estimate the impact of taxes on immigration into the 2,551 Swiss municipalities. As we observe the immigration but not the emigration of households, only the pull factors of migration can be measured. However, as Dowding et al. (1994) conclude, taxes are a pull rather than a push factor, in terms of migration.

Surely, a unilateral analysis would result in a loss of information, compared to an analysis of bilateral flows. However, such an investigation offers a considerable advantage: the analysis of multilateral flows requires a clutch of data for all countries, regarding the factors that determine migration. However, in every database, there are only a few variables available. For this reason, there is substantial danger of omitted-variable bias, if only cross-sectional data were analyzed. ${ }^{3}$ Instead, an analysis of unilateral migration flows need not control for overall locational factors at the national level (e.g. federal social insurance, federal employment laws), as they are applicable to all municipalities in Switzerland. A relatively large share of the factors influencing migration decisions can therefore be ignored. Further, one can control for most of the other agglomeration-specific factors that determine the attractiveness of a municipality by using cluster dummy variables.

\footnotetext{
${ }^{2}$ Equation (6) is equivalent to 'case 2' of Guimarães et al. (2003), where each location decision is based on a vector of common determinants for groups of individuals.

${ }^{3}$ By using multilateral panel data, one can preclude such problems.
} 
When short distances are involved, the supply of public goods in a specific municipality can also be accessed by the inhabitants of neighboring municipalities (e.g. regional hospitals, secondary schools, cultural activities). Hence, within agglomerations, the supply of public goods is more or less homogeneous; therefore, if one applies agglomerative clustering and controls for the urbanity level of municipalities, one need not control for public-goods provision. Then, the impact of taxes vis-à-vis immigration decisions can be identified, as income taxes differ substantially at a level more fundamental than the clustering level namely, at the municipality level.

\section{Dominance analysis}

By comparing the regression results, we get an initial impression of the absolute relevance of taxes for the migration decision. On the other hand, nothing can be said about the relative impact of taxes compared to other locational factors. In order to get an insight into this question, one has to extend the basic regression results or retransform the coefficients with the help of different methodological approaches (see e.g. Bring 1994). Unfortunately, almost all of the existing methods addressing the analysis of relative importance of predictor variables are applicable only to OLS models. One of the few exceptions is the 'dominance analysis' method of Budescu (1993). This method has the advantage that it can be applied to nonlinear regression models if some suitable goodness-of-fit-instruments exist. For example, Azen and Traxel (2009) apply this method to logistic regression. We would follow this approach and apply the method to all the three count data models.

Budescu (1993, 544) presumes the fulfillment of three conditions in the analysis of importance. First, importance is defined in terms of a variable's 'reduction of error' in predicting $y$. Second, the analysis allows for a direct comparison of relative importance and does not rely on inferred measures. Third, importance reflects a variable's direct effect, total effect, and partial effect. Specifically, the starting point of the dominance approach is an ordinal scaled comparison of the different explanatory variables. The impact $x_{i}$ on the outcome $y$ dominates ("is more important than”) another impact $x_{j}$ if and only if

$$
R^{2}\left(y \cdot x_{i}, x_{h}\right)-R^{2}\left(y \cdot x_{h}\right) \geq R^{2}\left(y \cdot x_{j}, x_{h}\right)-R^{2}\left(y \cdot x_{h}\right),
$$


for all the possible subsets of $\boldsymbol{x}_{\boldsymbol{h}}\left(x_{i}, x_{j} \notin \boldsymbol{x}_{\boldsymbol{h}}\right) . R^{2}$ is the goodness-of-fit measure of the respective subsets. For the following analysis, we use McFadden's pseudo $R^{2}$ (McFadden 1973) as goodness-of-fit measure:

$$
\text { pseudo } R^{2}(y \cdot x)=1-\left[\frac{l l(y \cdot x)}{l l(0)}\right]
$$

where $l l(y \cdot \boldsymbol{x})$ is the log-likelihood of the respective models and $l l(0)$ the one of the constant only model.

On the basis of this dominance analysis, Budescu (1993) proposes a subsequent measure of the 'mean usefulness' of $x_{i}$ :

$$
C_{x_{i}}=\sum_{k=0}^{p-1} C_{x_{i}}^{(k)} / p
$$

where $p$ is the number of explanatory variables in the full model and $C_{x_{i}}^{(k)}$ the mean usefulness across all $\left(\begin{array}{c}p-1 \\ k\end{array}\right)$ models including $k+1$ variables ( $x_{i}$ and $k$ other variables):

$$
C_{x_{i}}^{(k)}=\sum\left[R^{2}\left(y \cdot x_{i}, x_{h}\right)-R^{2}\left(y \cdot x_{h}\right)\right] /\left(\begin{array}{c}
p-1 \\
k
\end{array}\right)
$$

Finally, in order to get the relative importance weights of the impact of one variable compared to all the other variables, one has to calculate the importance weights $W_{x_{i}}$ :

$$
W_{x_{i}}=C_{x_{i}} / \sum_{j=0}^{p} C_{x_{j}}
$$

According to Budescu (1993), this relative importance approach is fully consistent with dominance analysis only if the latter does give a clear ordering of the variable's importance. Therefore, one should interpret the weights of variables only where dominance analysis does give clear results.

\section{$5 \quad$ The Swiss income tax system}

In terms of revenue, the personal income tax is the most important tax in Switzerland, generating 51.4 billion Swiss francs (CHF) (equivalent to 9.0\% of GDP) in 2010. All three levels of governments have the authority to tax personal income; $47.9 \%$ of personal income tax revenue goes to the cantons, $32.7 \%$ to the municipalities, and only $19.4 \%$ to the federal 
government. Cantons are fully sovereign in fixing their own tax schedules. ${ }^{4}$ Municipalities can generally apply a multiplier to the cantonal income tax, or participate in other ways (e.g. share tax earnings or apply extraordinary schedule). As only a small share of total income tax earnings goes to the federal government, overall income tax rates differ substantially among and within cantons. A single household that earns CHF125,000 must pay 8.4\% income taxes in Wollerau (Canton of Zug), but 24.7\% in Montalchez (Canton of Neuenburg). ${ }^{5}$ For a household with a gross income of CHF500,000, the lowest statutory tax rate is levied in Wollerau (Canton of Schwyz), at 15.9\%; the highest tax rate, 37.9\%, is levied in Vermes (Canton of Jura). ${ }^{6}$ However, even within cantons, tax rates differ significantly: on average, the differential between the maximum and minimum tax rate within cantons is 3.9 (5.0) percentage points, among single households with gross incomes of CHF125,000 (CHF500,000).

\section{$6 \quad$ Data}

As explanatory variables, we use data from the published migration database of the Swiss Federal Statistical Office (SFSO). Data are available for the year 2010 and are aggregated at the municipal level. The statistics include information on the age of the persons therein, the continent of origin, and whether they lived in another municipality, canton, or country in the previous year. Mobility should be highest among the working-age population, and so we look at immigrants aged 25-54 years old who lived abroad in the previous year. In doing so, we focus on permanent residents whose origin is an EU/EFTA or North American country. By using this information, we can ensure that only immigration from industrialized countries is analyzed: asylum-seekers are not considered.

Table 1 provides some first impressions of the dispersions of these immigrants into any of the 2,551 Swiss municipalities. In 26\% of all Swiss municipalities, immigration of the analyzed subgroup was zero. As is typical for count data, there is an excess of zeros and a right-skewed distribution. Also, the standard deviation is more than eight times larger than the unconditional mean, indicating that overdispersion could be substantial.

\footnotetext{
${ }^{4}$ However, the Federal Supreme Court of Switzerland restricted the autonomy of the cantons by declaring that regressive tax schedules violate the constitution. Furthermore, the tax base is widely harmonized by federal law.

${ }^{5}$ Including federal taxes (2.9\%); rates are applicable to taxable income from the year 2010.

${ }^{6}$ Including federal taxes of $9.3 \%$.
} 
Table 1: Distribution of 25-54-year-old foreign immigrants (origin of EU/EFTA or North American countries) in Swiss municipalities, 2010

Total

\begin{tabular}{lrrrrrrrrrrrr} 
Number of immigrants (n) & 0 & 1 & 2 & 3 & 4 & 5 & 6 & 7 & 8 & 9 & $10+$ & 42,247 \\
\hline Number of municipalities (m) & 661 & 334 & 215 & 193 & 116 & 101 & 92 & 80 & 63 & 54 & 642 & 2,551 \\
& $26 \%$ & $13 \%$ & $8 \%$ & $8 \%$ & $5 \%$ & $4 \%$ & $4 \%$ & $3 \%$ & $2 \%$ & $2 \%$ & $25 \%$ & $100 \%$ \\
mean (n) & & & & & & & & & & & & 16.6 \\
s.d. (n) & & & & & & & & & & & & 139.2 \\
\hline
\end{tabular}

Both the distribution of the number of immigrants across municipalities and the regional dispersion are heterogeneous (see Figure 1). Most people move into cities or the respective agglomerations: The five cities of Zurich, Geneva, Basel, Lausanne, and Bern, as well as their respective agglomerations accounted for 55\% of all immigrants in the year 2010. This is a first indication that there exists some form of spatial correlation (i.e. agglomerative clustering) among nearby municipalities, as hypothesized above.

Figure 1: Regional distribution of 25-54-year-old foreign immigrants (origin of EU/EFTA or North American countries) across Swiss municipalities, 2010

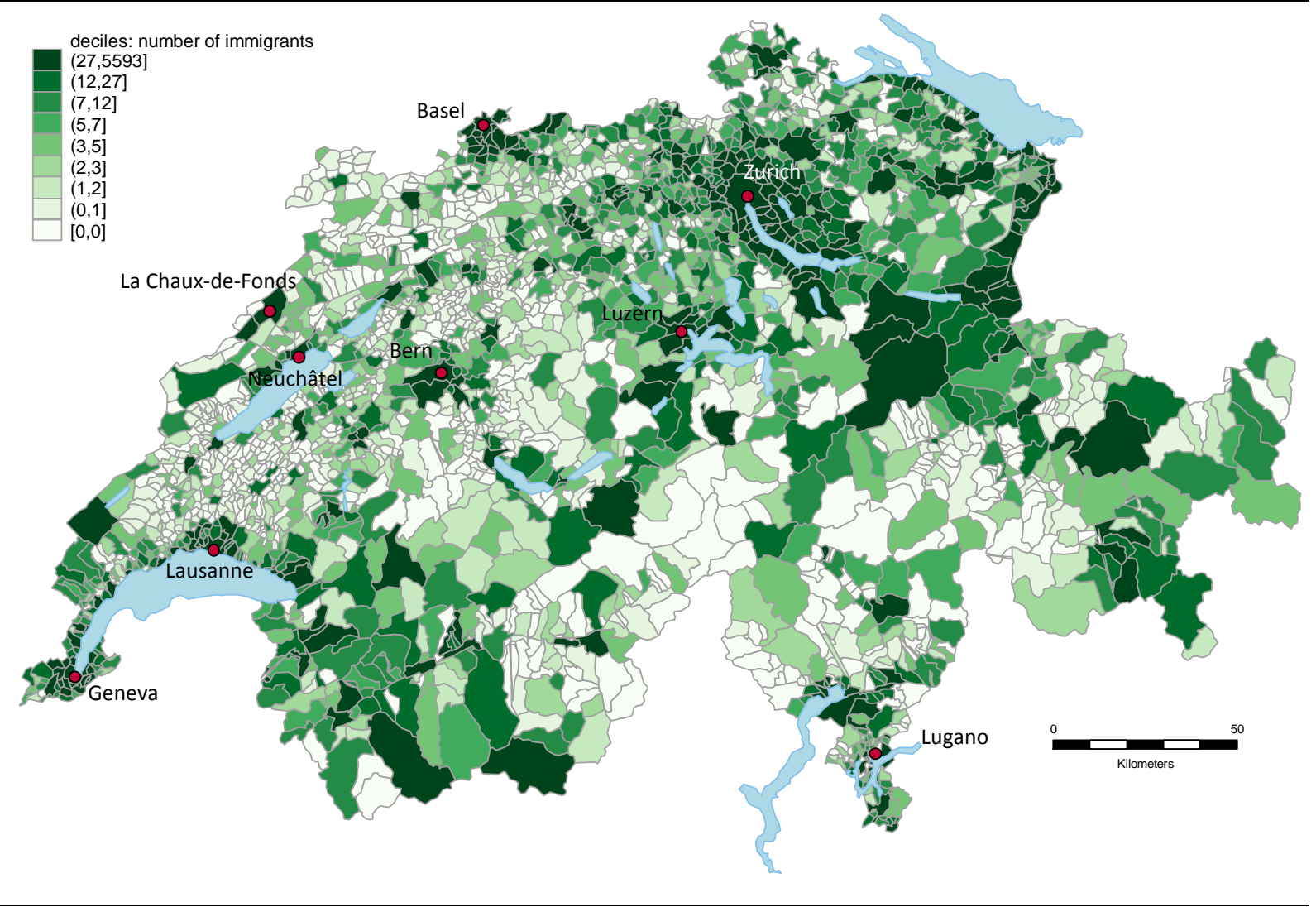

Sources: Author's own illustration, using data from the SFSO (GEOSTAT and population statistics) and the spmap module (STATA) of Pisati (2007). 
As a tax variable, the average income tax rate (including cantonal, communal, and church taxes) $^{7}$ of a single household earning a gross income of CHF125,000 is considered. ${ }^{8}$ This threshold is chosen for a specific reason: some of the foreign population (i.e. people with a one-year stay permit or a short-term permit) is taxed at the source, if the income does not exceed CHF120,000. Because a cantonal average rate is imposed, taxation at the source does not consider the place of residence within a canton. However, if one earns more than CHF120,000, ordinary income taxation is applied. Empirical evidence suggests that the mobility of households increases with income; therefore, this source-based taxation should not have a considerable impact on the reliability of the empirical results, because the threshold is rather moderate. Sensitivity analysis of the regression results (section 7) will determine whether this assumption is valid.

As control variables, different municipal-level variables are included in the econometric model. First, we include the adjusted net median income (med_inc; 2008 values) in order to control for wage differences. Second, the number of full-time employees per 1,000 inhabitants in the second and third sector (fte2, fte3; 2008 values) is included in order to map labor demand and economic structure. Third, the unemployment rate (unemp; 2010 values) and the share of people aged 25-64 years with a secondary or tertiary education (secondary, tertiary; 2000 values) are used as labor supply and labor quality proxies. Fourth, we draw on the median price of an apartment with four rooms in the respective region ${ }^{9}$ (p_housing; 2010 values) to control for housing market conditions. Fifth, we include the number of cross-border commuters (crosser; average of all 2010 quarters), because commuting is both an alternative to migration and a substitute for employers hiring staff from distant locations. Sixth, the shortest distance to the next agglomeration center in meters (dist_center) is included. ${ }^{10}$ Seventh, the population and its squared number (pop, pop2; 2010 values) are used in order to control for differences in urbanity among municipalities. Eighth, the number of people in the respective municipality of German, French, Italian, Portuguese, Spanish, or British nationality (German, French, Italian, Port, Spanish, UK; 2010 values) is included as proxy for network

\footnotetext{
${ }^{7}$ Federal income taxes are not included, because they are equal across regions.

${ }^{8}$ According to SFSO, the median gross wage of a fully employed graduate is CHF102,200, while the median gross wage of an executive is CHF121,500 (2011 values).

${ }^{9}$ Source: Wüest and Partner (2011). These data are not available at the municipality level, but only at a more aggregated level, which is the so-called spatial-mobility region (data). Spatial mobility regions are relatively homogenous spatial groups with a common regional center, and they can be interpreted as small job-market regions. The regions are defined as per the classification from official SFSO statistics.

${ }^{10}$ I am grateful to Raphaël Parchet for providing me with these data. For more information on this variable, see Eugster and Parchet (2013).
} 
effects. These six countries are the largest EU diasporas in Switzerland. Lastly, two dummy variables are included, each of which takes a value of 1 if the municipality is classified as a tourism resort or is rural. Summary statistics for the control variables are found in Table 2.

Table 2: Summary statistics of municipal data

\begin{tabular}{lrrrrr} 
variable & median & min & mean & max & sd \\
\hline $\mathrm{n}$ & 3 & 0 & 21.55 & 6723.00 & 176.43 \\
ts_125000 & 16.52 & 5.44 & 16.08 & 21.80 & 2.22 \\
med_inc & $50,000.00$ & $4,900.00$ & $49,727.71$ & $91,600.00$ & $10,139.01$ \\
fte2 & 68.20 & 0.00 & 100.69 & $2,099.69$ & 118.11 \\
fte3 & 105.40 & 0.00 & 150.37 & $2,117.89$ & 153.31 \\
unemp & 2.54 & 0.00 & 2.78 & 11.56 & 1.60 \\
secondary & 54.04 & 23.68 & 53.68 & 77.78 & 6.69 \\
tertiary & 17.61 & 1.46 & 18.81 & 52.43 & 7.54 \\
p_housing & 486,000 & 338,000 & 537,439 & $1,231,000$ & 156,005 \\
crosser & 1.7 & 0.0 & 91.8 & $32,197.0$ & 892.1 \\
dist_center & $11,967.00$ & 0.00 & $15,178.70$ & $128,563.00$ & $12,792.08$ \\
pop & 1,193 & 32 & $3,132.71$ & 372,857 & $10,872.60$ \\
pop2 & $1,423,249$ & 1,024 & $128,000,000$ & $1 . E+11$ & $3 . E+09$ \\
rural & 0 & 0 & 0.47 & 1 & 0.50 \\
tourism & 0 & 0 & 0.06 & 1 & 0.23 \\
German & 0.02 & 0.00 & 0.02 & 0.26 & 0.02 \\
French & 0.00 & 0.00 & 0.01 & 0.15 & 0.02 \\
Italian & 0.01 & 0.00 & 0.02 & 0.28 & 0.03 \\
Port & 0.01 & 0.00 & 0.02 & 0.31 & 0.03 \\
Spanish & 0.00 & 0.00 & 0.00 & 0.08 & 0.01 \\
UK & 0.00 & 0.00 & 0.00 & 0.09 & 0.01 \\
\hline
\end{tabular}

Number of observations: 2,497 municipalities (total of 2010: 2,551)

As a cluster variable, we use the agglomeration definition from official SFSO statistics. According to SFSO classification, the 2,551 Swiss municipalities are grouped into 55 agglomerations. Municipalities that are not assigned to an agglomeration are coded as zero; together, they build a hybrid agglomeration.

For 54 municipalities some data are missing, and so these are omitted from the analysis. In total, then, the dataset includes 2,497 municipalities (55 agglomerations).

With regard to dominance analysis only, it seems adequate to group the closely related variables together in order to facilitate interpretation of the importance weight and to mitigate the problem of multicollinearity. Therefore, we focus on six vectors $x_{i}$ which group the 
variables as follows: (1) the labor-market (med_inc, fte2 fte3, unemp) and labor skill (tertiary and secondary) variables so as to form a common 'labor' indicator; (2) population variables (pop and pop2) and urbanity dummies (rural, tourism, and dist_center) so as to form a common urbanity indicator; (3) a network indicator (consisting of German, French, Italian, Port, Spanish, and UK); (4) a housing market indicator (consisting of the p_housing variable); (5) the cross-border commuter variable ${ }^{11}$; and (6) the tax variable.

\section{$7 \quad$ Results}

Table 3 shows the results by estimating equation (6) with the help of three statistical models: (1) the fixed-effects Poisson regression model; (2) the negative binomial (type 2; NB2) regression model, and (3) the zero-inflated negative binomial (ZINB) regression model. The negbin model has the same conditional mean as the Poisson regression model but explicitly allows one to account for overdispersion by estimating the overdispersion-coefficient alpha (the negbin nests the Poisson for alpha $=0$ ). The ZINB model is able to handle not only overdispersion but also the problem of excess zeros by simultaneously estimating a logit (for the excess zeros) and a negbin regression model (for the other zeros and counts).

All the estimates are based on a cluster-robust variance estimator [which is in the case of Poisson regression equivalent to the robust estimator proposed by Wooldridge (1999)]. In all three models, the tax variable is significant negative at the $0.1 \%$ level (see Table 3 in the appendix). The tax parameter estimates are virtually identical, ranging between -0.064 (main model of the ZINB) and -0.067 (Poisson). In terms of incidence rate ratios $[\exp (-0.064)$; $\exp (-0.067)]$, a one-percentage-point increase in the municipality tax rates would lead to a decrease in the number of intra-national migrants by a factor of 0.94 .

\footnotetext{
${ }^{11}$ The number of cross-border commuters who work in a specific municipality can influence migration flows in two ways. First, for a person who starts to work in Switzerland, commuting over the border is an alternative to the decision to migrate to Switzerland; thus, migration and commuting are supply-side substitutes. Second, enterprises that are located in nearby frontiers can recruit across borders, whereas other enterprises located less favorable need to hire employees from distant locations if they cannot find any labor force in the local labormarket. Therefore, migration and commuting are also demand-side substitutes. Because of these different mechanisms, it is not clear as to under which group this variable can be subsumed: From a supply-side perspective, one would categorize this variable as an urbanity indicator (proxy for the distance to the frontier); while from a demand-side perspective, one would classify it as a labor-market indicator.
} 
Table 3: Regression results - Pull factors of migration for population aged 25-54 years

\begin{tabular}{|c|c|c|c|c|}
\hline & poisson & negbin & zinb (main) & zinb (inflate) \\
\hline ts_125000 & $\begin{array}{l}-.066563 * * * \\
(.0099334)\end{array}$ & $\begin{array}{l}-.0653648 * * * \\
(.0122866)\end{array}$ & $\begin{array}{l}-.0640325 * * * \\
(.0168282)\end{array}$ & $\begin{array}{l}-0.0153192 \\
(.0285185)\end{array}$ \\
\hline med_inc & $\begin{array}{l}2.26 \mathrm{E}-06 \\
(6.11 \mathrm{e}-06)\end{array}$ & $\begin{array}{l}.0000102^{*} \\
(4.05 \mathrm{e}-06)\end{array}$ & $\begin{array}{l}1.52 \mathrm{E}-06 \\
(3.87 \mathrm{e}-06)\end{array}$ & $\begin{array}{l}1.44 \mathrm{E}-06 \\
(6.71 \mathrm{e}-06)\end{array}$ \\
\hline fte2 & $\begin{array}{l}3.31 \mathrm{E}-04 \\
(.0002436)\end{array}$ & $\begin{array}{l}.0008035^{* *} \\
(.000291)\end{array}$ & $\begin{array}{l}.0004279 * * \\
(.0001361)\end{array}$ & $\begin{array}{l}-4.14 \mathrm{E}-04 \\
(.0003086)\end{array}$ \\
\hline fte3 & $\begin{array}{l}.0006981^{* * * *} \\
(.000128)\end{array}$ & $\begin{array}{l}4.89 \mathrm{E}-04 \\
(.0002841)\end{array}$ & $\begin{array}{l}4.11 \mathrm{E}-04 \\
(.000211)\end{array}$ & $\begin{array}{l}-2.66 \mathrm{E}-04 \\
(.0004685)\end{array}$ \\
\hline unemp & $\begin{array}{l}.1243623^{* * * *} \\
(.0272935)\end{array}$ & $\begin{array}{l}.086174 * * * \\
(.0185376)\end{array}$ & $\begin{array}{l}.0676017 * * \\
(.0212057)\end{array}$ & $\begin{array}{l}-.1058623 * * * \\
(.0257376)\end{array}$ \\
\hline secondary & $\begin{array}{l}-.0331223^{* * *} \\
(.0078579)\end{array}$ & $\begin{array}{l}-.023201^{* * *} \\
(.0067284)\end{array}$ & $\begin{array}{l}-.0281829 * * * \\
(.0054459)\end{array}$ & $\begin{array}{l}-.0206685^{* *} \\
(.0064564)\end{array}$ \\
\hline tertiary & $\begin{array}{l}-3.92 \mathrm{E}-03 \\
(.0062736)\end{array}$ & $\begin{array}{l}-3.29 \mathrm{E}-03 \\
(.0036002)\end{array}$ & $\begin{array}{l}8.72 \mathrm{E}-05 \\
(.0035066)\end{array}$ & $\begin{array}{l}-.0184431^{* *} \\
(.005972)\end{array}$ \\
\hline p_housing & $\begin{array}{l}1.50 \mathrm{e}-06^{* * *} \\
(1.78 \mathrm{e}-07)\end{array}$ & $\begin{array}{l}9.45 \mathrm{e}-07 * * * \\
(2.85 \mathrm{e}-07)\end{array}$ & $\begin{array}{l}9.17 \mathrm{e}-07^{* *} \\
(3.27 \mathrm{e}-07)\end{array}$ & $\begin{array}{l}1.14 \mathrm{E}-07 \\
(1.28 \mathrm{e}-06)\end{array}$ \\
\hline crosser & $\begin{array}{l}-.0000472 * \\
(.0000194)\end{array}$ & $\begin{array}{l}-.0002937 * \\
(.0001351)\end{array}$ & $\begin{array}{l}-.0002211^{* *} \\
(.0000851)\end{array}$ & $\begin{array}{l}-6.86 \mathrm{E}-03 \\
(.0161109)\end{array}$ \\
\hline dist_center & $\begin{array}{l}-.0000195^{* * *} \\
(3.00 \mathrm{e}-06)\end{array}$ & $\begin{array}{l}-.0000108^{* * *} \\
(2.41 \mathrm{e}-06)\end{array}$ & $\begin{array}{l}-9.05 \mathrm{e}-06^{* * *} \\
(2.20 \mathrm{e}-06)\end{array}$ & $\begin{array}{l}-.0000103^{* *} \\
(3.30 \mathrm{e}-06)\end{array}$ \\
\hline pop & $\begin{array}{l}.0000436^{* * *} \\
(6.76 \mathrm{e}-06)\end{array}$ & $\begin{array}{l}.0001492^{* *} \\
(.0000495)\end{array}$ & $\begin{array}{l}.000126^{* * *} \\
(.0000309)\end{array}$ & $\begin{array}{l}-.0042688^{* * * *} \\
(.0003528)\end{array}$ \\
\hline pop2 & $\begin{array}{l}-9.03 \mathrm{e}-11^{* * *} \\
(1.64 \mathrm{e}-11)\end{array}$ & $\begin{array}{l}-3.64 \mathrm{e}-10^{* *} \\
(1.28 \mathrm{e}-10)\end{array}$ & $\begin{array}{l}-3.04 \mathrm{e}-10^{* * *} \\
(7.92 \mathrm{e}-11)\end{array}$ & $\begin{array}{l}1.15 \mathrm{e}-08^{* * *} \\
(7.95 \mathrm{e}-10)\end{array}$ \\
\hline rural & $\begin{array}{l}-.9235919 * * * \\
(.042522)\end{array}$ & $\begin{array}{l}-.671079 * * * \\
(.0989389)\end{array}$ & $\begin{array}{l}-.5894947 * * * \\
(.0449991)\end{array}$ & $\begin{array}{l}-.7318749 * * * \\
(.2174286)\end{array}$ \\
\hline tourism & $\begin{array}{l}\text { 6.02E-02 } \\
(.1511293)\end{array}$ & $\begin{array}{l}.202487 * * * \\
(.0487893)\end{array}$ & $\begin{array}{l}.1692562 * * * \\
(.0399192)\end{array}$ & $\begin{array}{l}-.2691728^{*} \\
(.1332363)\end{array}$ \\
\hline German & $\begin{array}{l}10.02196 * * * \\
(.9493461)\end{array}$ & $\begin{array}{l}16.77612 * * * \\
(.8906221)\end{array}$ & $\begin{array}{l}12.16493^{* * *} \\
(.8223827)\end{array}$ & $\begin{array}{l}-27.47983^{* * *} \\
(3.042733)\end{array}$ \\
\hline French & $\begin{array}{l}7.23 E-01 \\
(3.452204)\end{array}$ & $\begin{array}{l}4.37807^{* *} \\
(1.377561)\end{array}$ & $\begin{array}{l}3.665687 * \\
(1.837663)\end{array}$ & $\begin{array}{l}-11.72041^{* *} \\
(3.770051)\end{array}$ \\
\hline Italian & $\begin{array}{l}8.25103 * * * \\
(.9286557)\end{array}$ & $\begin{array}{l}7.822829 * * * \\
(.4071646)\end{array}$ & $\begin{array}{l}7.271939 * * * \\
(.5368628)\end{array}$ & $\begin{array}{l}-8.656796^{* * *} \\
(1.953708)\end{array}$ \\
\hline Port & $\begin{array}{l}3.990379 * * * \\
(1.053274)\end{array}$ & $\begin{array}{l}5.520954^{* * *} \\
(.65394)\end{array}$ & $\begin{array}{l}3.434853^{* * *} \\
(.5473779)\end{array}$ & $\begin{array}{l}-17.31288^{* * *} \\
(5.005666)\end{array}$ \\
\hline Spanish & $\begin{array}{l}-3.97 \mathrm{E}+00 \\
(6.999264)\end{array}$ & $\begin{array}{l}-1.58 \mathrm{E}+00 \\
(5.410094)\end{array}$ & $\begin{array}{l}2.51 \mathrm{E}-01 \\
(5.168726)\end{array}$ & $\begin{array}{l}7.12 \mathrm{E}+00 \\
(15.02206)\end{array}$ \\
\hline UK & $\begin{array}{l}18.51448^{* *} \\
(6.722732)\end{array}$ & $\begin{array}{l}14.96777 * * \\
(5.685464)\end{array}$ & $\begin{array}{l}10.31288^{*} \\
(4.966951)\end{array}$ & $\begin{array}{l}-35.13505 * \\
(17.59573)\end{array}$ \\
\hline constant & $\begin{array}{l}3.126712 * * * \\
(.621461)\end{array}$ & $\begin{array}{l}1.766789 * \\
(.7680465)\end{array}$ & $\begin{array}{l}2.869278^{* * *} \\
(.609731)\end{array}$ & $\begin{array}{l}5.162881^{* * *} \\
(.8029838) \\
\end{array}$ \\
\hline lnalpha & & $\begin{array}{l}-.6639532 * * \\
(.234459)\end{array}$ & $\begin{array}{l}-1.039326^{* * *} \\
(.139221)\end{array}$ & \\
\hline log likelihood & -10950.57 & -6322.228 & & 92.755 \\
\hline
\end{tabular}

Note: Standard errors in parentheses; * $\mathrm{p}<0.05$, ** $\mathrm{p}<0.01, * * * \mathrm{p}<0.001$; fixed effects not shown 
According to the ZINB model, the income tax burden is significant only in the main part of the model, but not in its logit part. This result indicates that municipalities with high tax levels do not have a higher probability of excess-zero immigration.

Concerning the labor-market variables, the unemployment rate and the skill level (i.e. secondary education) significantly impact where immigrants will settle. The positive impact of the unemployment rate does not seem to align with common labor-market assumptions, and therefore should relate to indirect correlations (e.g., immigrants mostly move to cities where unemployment rates are, on average, higher than in rural regions). The same unexpectedly positive correlation between housing prices and immigration should relate to these indirect effects.

Municipalities with a high number of cross-border commuters do have statistically significantly lower immigration rates compared with the average municipality. This finding aligns with the assumptions made above, vis-à-vis the supply- and demand-side aspects of labor-market.

Further, all the urbanity variables are statistically significant. A longer distance to the next center substantially decreases the incentive to move into the respective municipality. Tourism municipalities and urban municipalities with large populations have higher immigration rates, while rural municipalities have lower immigration rates compared to the average municipality. Finally, network effects are important for immigration decisions: regarding the six largest EU-based diasporas in Switzerland, for all except the Spanish one (i.e., German, French, Italian, Portuguese, and British), network effects significantly positively impact the number of newly-arrived immigrants.

The likelihood-ratio test strongly rejects the Poisson model in favor of the NB2 model. Further, the Vuong test (Vuong 1989) suggests the ZINB model favorable compared to the NB2 model. These results indicate that the data show the characteristics of both overdispersion and excess zeros.

Dominance analysis according to equation (7) gives the following ordering of importance:

$$
\text { urbanity }>(\text { labor; network })>(\text { crosser; housing; tax }) \text {. }
$$

For all the 16 pairwise comparisons, urbanity dominates the labor-market and the network indicator; the latter two dominate the crosser, housing, and tax indicators. There is no clear ordering between the crosser, housing, and tax indicators, as well as between the labor and network indicators. The result of dominance analysis holds for both the NB2 and ZINB 
models. However, for the Poisson model, dominance analysis is not possible, since in 11 out of 63 regression models, the model did not converge within 1,000 iterations. This problem could indicate that the Poisson regression model is not adequate for this migration analysis.

Next, we calculate the importance weights for the ZINB and NB2 models, according to equation (11). The results suggest that the urbanity, labor-market, and network characteristics are by far the most important pull factors in choosing the initial residence location (see Figure 2). Independent of the chosen statistical model, these factors explain at least 75 percent of the overall goodness of fit (excluding the impact of the cluster dummy variables). According to the best-fitted model, ZINB, the importance of the urbanity factors on the location choice is about 6.0 times higher than the tax rate $(.377 / .063)$.

Figure 2: Relative impact of municipality characteristics on immigration

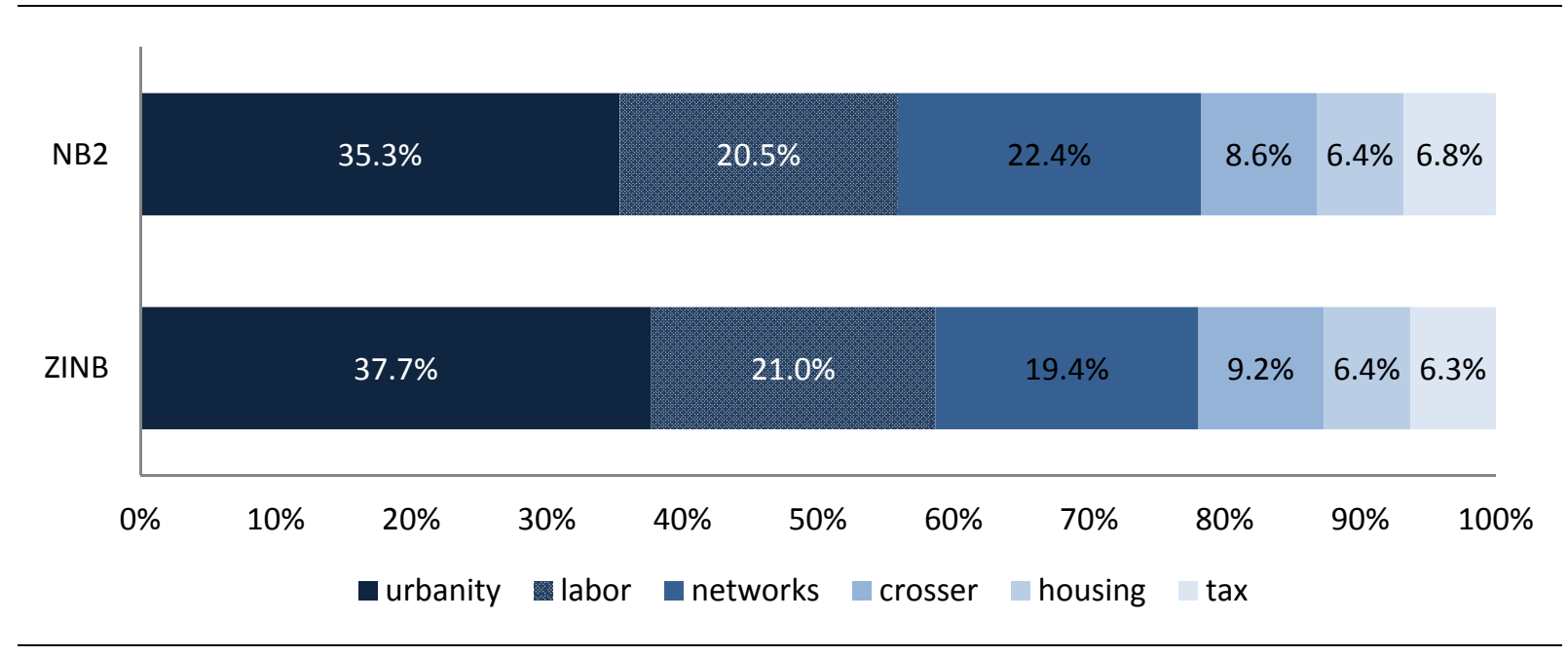

The labor-market conditions (i.e., supply- and demand-side proxies) and the network effects can both explain about $20 \%$ of the model's goodness of fit; their impact on location choice is about 3 times larger than that of the income tax rates, all other things being equal. This finding suggests that the immigrants have the strong preference to live within the same municipality where they work or where their diaspora members live. Overall, the regression and dominance analysis results indicate that the relative influence of income taxes on migration decisions is only modest.

One potential explanation as to why the impact of taxes on the migration decision is rather low could be that foreign residents with one-year permits and a gross income of less than CHF120,000 are taxed at source. For these persons, the average tax burden is constant within cantons and only differs among cantons. Several agglomerations are cross-border, meaning 
that they include municipalities from different cantons. However, for agglomerations that include only municipalities from one canton, the tax-sensitivity of the people who are taxed at the source cannot be measured, because in this case, the cluster fixed effects fully capture intra-cantonal tax differentials. This leads to a potential downward bias in the tax coefficient.

However, there are two points that likely reduce this problem. First, as the literature suggests, migration due to tax differentials is a phenomenon that relates almost exclusively to highskilled and affluent households. Low-income earners, on the other hand, are seldom taxsensitive (Schmidheiny 2006; Liebig and Sousa-Poza 2006; Liebig et al. 2007). Second, immigrants who are tax-sensitive but who are initially taxed at the source due to their low income eventually become inhabitants with long-term permits, if they continue to live in Switzerland. Inhabitants with long-term permits are taxed on an ordinary basis; therefore, immigrants who are initially planning to stay for a longer time in Switzerland do have some incentive to settle in low-tax municipalities, even if they cannot benefit immediately from those conditions. Nevertheless, we undertake below a sensitivity analysis, in order to determine whether this assumption is true, or if the initial results could be biased.

\section{Sensitivity analysis 1: Intra-national migration}

To check the sensitivity of the relative impact measures with respect to the potential bias problem (and also the adequacy of the statistical model in general), we repeat the regression analysis with other population subgroups. We calculate the intra-national migration behavior of foreigners (once again only those originating from the EU/EFTA or the North American countries and aged 25-54 years) and the Swiss who already live in Switzerland but have changed their place of residence from one municipality to another in 2010. Since the initial results show that the ZINB model is the most adequate one, the Poisson and NB2 models are not considered any longer here. Because the migration behavior of the Swiss people should not depend on network effects, we run the regressions for this group in the absence of the network variables. The regression results are found in Table 4. 
Table 4: Sensitivity analysis 1 - intra-national migration of foreigners and Swiss

\begin{tabular}{|c|c|c|c|c|}
\hline & \multicolumn{2}{|c|}{ Foreigners } & \multicolumn{2}{|c|}{ Swiss } \\
\hline & zinb(main) & zinb(inflate) & zinb(main) & zinb(inflate) \\
\hline ts_125000 & $\begin{array}{l}-.0595082 * * \\
(.0198282)\end{array}$ & $\begin{array}{l}.0558142 * \\
(.0267366)\end{array}$ & $\begin{array}{l}-.0558853 * \\
(.0229477)\end{array}$ & $\begin{array}{l}.2695571^{* * *} \\
(.043747)\end{array}$ \\
\hline med_inc & $\begin{array}{l}.0000165^{* * * *} \\
(4.23 \mathrm{e}-06)\end{array}$ & $\begin{array}{l}-.0000176^{* * *} \\
(3.63 \mathrm{e}-06)\end{array}$ & $\begin{array}{l}.0000158^{* * * *} \\
(3.56 \mathrm{e}-06)\end{array}$ & $\begin{array}{l}-.0000404^{* * *} \\
(7.21 \mathrm{e}-06)\end{array}$ \\
\hline fte2 & $\begin{array}{l}.0007231 * * \\
(.0002396)\end{array}$ & $\begin{array}{l}-.0012673 * * * \\
(.0003811)\end{array}$ & $\begin{array}{l}.0010934^{* * *} \\
(.0003096)\end{array}$ & $\begin{array}{l}-.001502 * * * \\
(.0000883)\end{array}$ \\
\hline fte3 & $\begin{array}{l}1.23 \mathrm{E}-04 \\
(.0001138)\end{array}$ & $\begin{array}{l}-.0030813^{* * *} \\
(.0004951)\end{array}$ & $\begin{array}{l}.0005324 * \\
(.0002326)\end{array}$ & $\begin{array}{l}.0007301 * \\
(.0003464)\end{array}$ \\
\hline unemp & $\begin{array}{l}.1013002^{* * * *} \\
(.013994)\end{array}$ & $\begin{array}{l}-.1344004 * * * \\
(.0327423)\end{array}$ & $\begin{array}{l}6.00 \mathrm{E}-02 \\
(.0345923)\end{array}$ & $\begin{array}{l}-.1511558 * * * \\
(.0025208)\end{array}$ \\
\hline secondary & $\begin{array}{l}-.0110392 * * \\
(.0037178)\end{array}$ & $\begin{array}{l}-.0330084 * * * \\
(.0030407)\end{array}$ & $\begin{array}{l}1.23 E-03 \\
(.0044394)\end{array}$ & $\begin{array}{l}-.0182918 * * * \\
(.0013565)\end{array}$ \\
\hline tertiary & $\begin{array}{l}-.0103985 * * \\
(.0034331)\end{array}$ & $\begin{array}{l}.0128503^{*} \\
(.005498)\end{array}$ & $\begin{array}{l}-3.88 \mathrm{E}-04 \\
(.0060763)\end{array}$ & $\begin{array}{l}-.007784 * \\
(.0032234)\end{array}$ \\
\hline p_housing & $\begin{array}{l}\text { 7.28e-07*** } \\
(1.25 \mathrm{e}-07)\end{array}$ & $\begin{array}{l}-1.47 \mathrm{E}-07 \\
(4.44 \mathrm{e}-07)\end{array}$ & $\begin{array}{l}1.24 \mathrm{E}-07 \\
(9.67 \mathrm{e}-08)\end{array}$ & $\begin{array}{l}8.50 \mathrm{E}-08 \\
(1.21 \mathrm{e}-07)\end{array}$ \\
\hline crosser & $\begin{array}{l}-.000255 * \\
(.0001133)\end{array}$ & $\begin{array}{l}-.0115241 * \\
(.0057168)\end{array}$ & $\begin{array}{l}-.0003505 * \\
(.0001755)\end{array}$ & $\begin{array}{l}.0234825^{* * * *} \\
(.006755)\end{array}$ \\
\hline dist_center & $\begin{array}{l}-.0000158 * * * \\
(1.64 \mathrm{e}-06)\end{array}$ & $\begin{array}{l}3.35 \mathrm{E}-06 \\
(2.70 \mathrm{e}-06)\end{array}$ & $\begin{array}{l}-.0000189 * * * \\
(1.63 \mathrm{e}-06)\end{array}$ & $\begin{array}{l}.0000126 * * \\
(4.00 \mathrm{e}-06)\end{array}$ \\
\hline pop & $\begin{array}{l}.0001204 * * \\
(.0000402)\end{array}$ & $\begin{array}{l}-.0089994 * * * \\
(.0005018)\end{array}$ & $\begin{array}{l}.0001543^{*} \\
(.0000616)\end{array}$ & $\begin{array}{l}-.0283539 * * * \\
(.0041022)\end{array}$ \\
\hline pop2 & $\begin{array}{l}-2.95 \mathrm{e}-10 * * \\
(1.04 \mathrm{e}-10)\end{array}$ & $\begin{array}{l}2.43 \mathrm{e}-08 * * * \\
(1.32 \mathrm{e}-09)\end{array}$ & $\begin{array}{l}-3.80 \mathrm{e}-10 * \\
(1.60 \mathrm{e}-10)\end{array}$ & $\begin{array}{l}7.56 \mathrm{e}-08 * * * \\
(1.09 \mathrm{e}-08)\end{array}$ \\
\hline rural & $\begin{array}{l}-.4319995 * * * \\
(.0489473)\end{array}$ & $\begin{array}{l}-.7659246 * \\
(.3071988)\end{array}$ & $\begin{array}{l}-.3630862 * * * \\
(.0933017)\end{array}$ & $\begin{array}{l}1.515871^{* * *} \\
(.2349878)\end{array}$ \\
\hline tourism & $\begin{array}{l}6.21 \mathrm{E}-02 \\
(.0581487)\end{array}$ & $\begin{array}{l}3.75 E-01 \\
(.2059414)\end{array}$ & $\begin{array}{l}2.30 \mathrm{E}-02 \\
(.0560293)\end{array}$ & $\begin{array}{l}5.82 \mathrm{E}-02 \\
(.1469385)\end{array}$ \\
\hline German & $\begin{array}{l}10.34771 * * * \\
(1.008271)\end{array}$ & $\begin{array}{l}-25.86979 * * * \\
(1.395754)\end{array}$ & & \\
\hline French & $\begin{array}{l}4.159694 * * * \\
(1.118993)\end{array}$ & $\begin{array}{l}-31.21315^{* * *} \\
(1.515308)\end{array}$ & & \\
\hline Italian & $\begin{array}{l}5.318316^{* * * *} \\
(1.24504)\end{array}$ & $\begin{array}{l}-16.64663 * * * \\
(1.592737)\end{array}$ & & \\
\hline Port & $\begin{array}{l}5.026448 * * * \\
(.5568951)\end{array}$ & $\begin{array}{l}-15.52423^{* * *} \\
(1.452522)\end{array}$ & & \\
\hline Spanish & $\begin{array}{l}4.55 \mathrm{E}+00 \\
(5.792371)\end{array}$ & $\begin{array}{l}-6.34 \mathrm{E}+00 \\
(3.399318)\end{array}$ & & \\
\hline UK & $\begin{array}{l}3.49155^{* * *} \\
(.8330158)\end{array}$ & $\begin{array}{l}-78.39675^{* * *} \\
(5.256701)\end{array}$ & & \\
\hline constant & $\begin{array}{l}2.028664 * * \\
(.723328)\end{array}$ & $\begin{array}{l}5.730691^{* * *} \\
(.6918576)\end{array}$ & $\begin{array}{l}3.288629 * * * \\
(.9741745)\end{array}$ & $\begin{array}{l}-1.665265^{* *} \\
(.5667446)\end{array}$ \\
\hline lnalpha & $\begin{array}{l}-1.155561^{* * *} \\
(.1187457)\end{array}$ & & $\begin{array}{l}-.9259435^{* * *} \\
(.1137976)\end{array}$ & \\
\hline log likelihood & -7612.203 & & -110 & 40.79 \\
\hline
\end{tabular}

Note: Standard errors in parentheses; ${ }^{*} \mathrm{p}<0.05$, $* * \mathrm{p}<0.01$, *** $\mathrm{p}<0.001$; fixed effects not shown 
Interestingly, the tax coefficients are smaller for both foreign and Swiss individuals when compared to previous results for the immigrants. These differences are statistically significant at the $0.1 \%$ level, indicating that the immigrants are, on average, more tax-sensitive than the existing long-term citizens of Switzerland. This is an interesting result, as newly immigrant people are expected to have less information on the Swiss income tax scheme than the native to Switzerland.

For the foreign intra-national migrants, dominance analysis generates the same ordering of importance as for the immigration group. However, for the Swiss intra-national migrants, the ranking is slightly different, as shown below:

$$
\text { urbanity }>\text { labor }>\text { (crosser; tax })>\text { housing. }
$$

In spite of the higher tax-sensitivity of the immigrants compared to the other two groups, the relative importance of income taxes is virtually identical across all the three subpopulation groups; the income tax variable explains less than $10 \%$ of the goodness-of-fit (see Figure 3 ).

Overall, this first sensitivity analysis suggests that even for people who grew up or have already lived for some years in Switzerland, the tax burden poses only a modest influence as a migration pull factor, even though the regression results and marginal effects show a significant impact.

\section{Figure 3: Relative impact of municipality characteristics on intra-national migration}

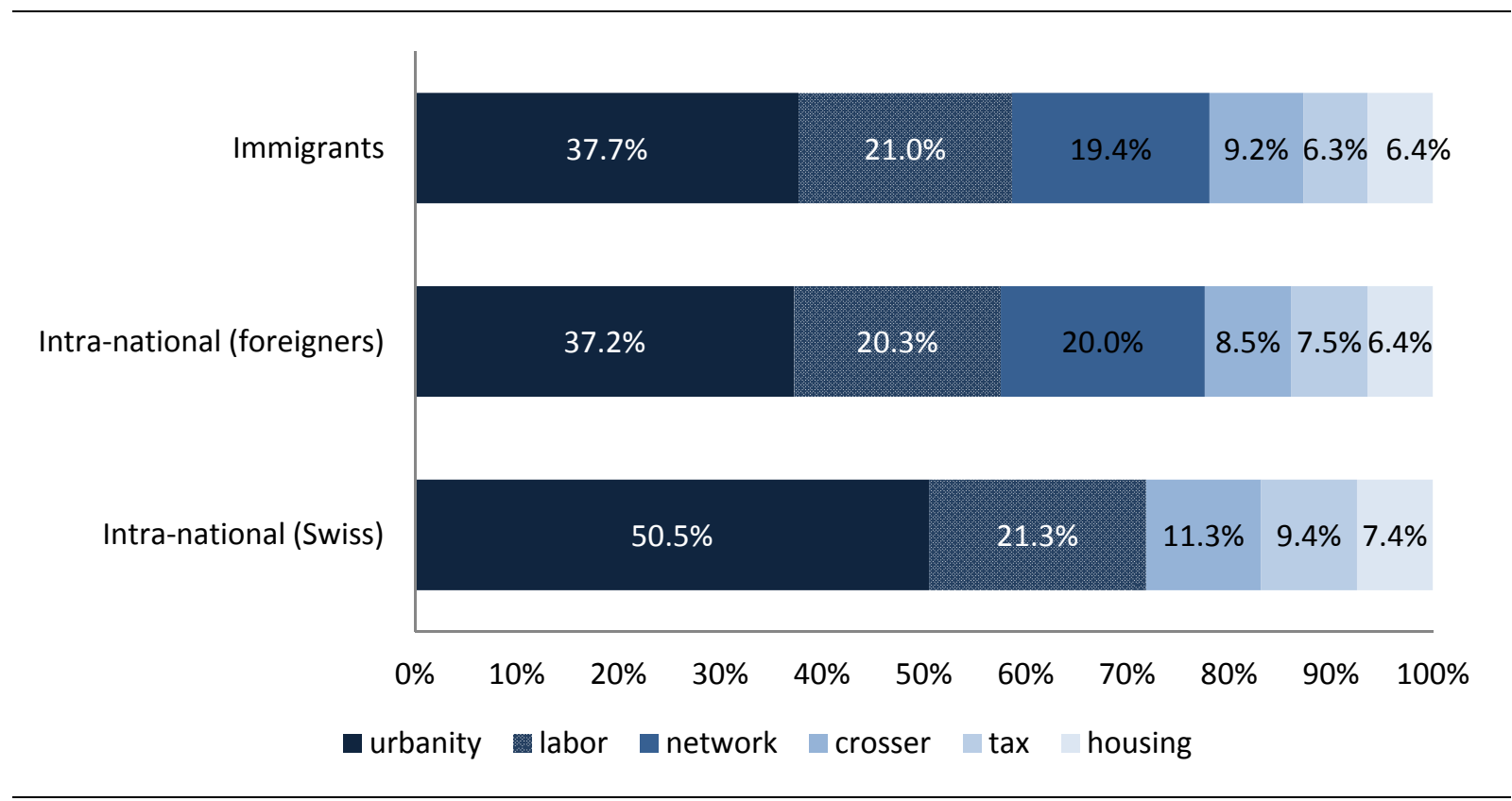

Note: Results are from ZINB regression 
Sensitivity analysis 2:

To determine whether the chosen threshold of CHF125,000 for the tax base influences the regression estimates, we analyze how the figures change when the tax base is altered. We conduct the same regressions as in the previous step; however, now we include the tax rates for gross incomes of CHF50,000, CHF80,000, CHF200,000, and CHF500,000. The regression results show that the tax rate for singles with a gross income of CHF80,000 has the highest impact on the number of immigrants, and decreases with increasing income (see Table 5). However, when varying the tax base, relative weight analysis indicates that the impact of the tax rate is low and rests stable within the range of 5.7\%-6.5\% (see Table 6). 
Table 5: Sensitivity analysis 2 - regression results for different tax rates

\begin{tabular}{|c|c|c|c|c|c|}
\hline & ts_50000 & ts_80000 & ts_125000 & ts 200000 & ts 500000 \\
\hline ts_ & $\begin{array}{c}-.0531999 * \\
(.0262485)\end{array}$ & $\begin{array}{c}-.0720072 * * * \\
(.0210504)\end{array}$ & $\begin{array}{c}-.0640325^{* * *} \\
(.0168282)\end{array}$ & $\begin{array}{c}-.0597282 * * * \\
(.0112986)\end{array}$ & $\begin{array}{c}-.0479513 * * * \\
(.0049319)\end{array}$ \\
\hline med_inc & $\begin{array}{l}\text { 3.88E-06 } \\
(3.76 \mathrm{e}-06)\end{array}$ & $\begin{array}{l}2.84 \mathrm{E}-06 \\
(3.89 \mathrm{e}-06)\end{array}$ & $\begin{array}{l}1.52 \mathrm{E}-06 \\
(3.87 \mathrm{e}-06)\end{array}$ & $\begin{array}{l}6.94 \mathrm{E}-07 \\
(3.61 \mathrm{e}-06)\end{array}$ & $\begin{array}{l}\text { 1.42E-06 } \\
(3.16 e-06)\end{array}$ \\
\hline fte2 & $\begin{array}{c}.0004548 * * \\
(.0001579)\end{array}$ & $\begin{array}{c}.0004336 * * \\
(.0001421)\end{array}$ & $\begin{array}{c}.0004279 * * \\
(.0001361)\end{array}$ & $\begin{array}{c}.0004135 * * \\
(.0001297)\end{array}$ & $\begin{array}{c}.0004257 * * \\
(.0001375)\end{array}$ \\
\hline fte3 & $\begin{array}{l}.0004391^{*} \\
(.0002009)\end{array}$ & $\begin{array}{c}.0004173^{*} \\
(.0002109)\end{array}$ & $\begin{array}{l}4.11 \mathrm{E}-04 \\
(.000211)\end{array}$ & $\begin{array}{l}\text { 4.08E-04 } \\
(.0002091)\end{array}$ & $\begin{array}{c}.0004398 * \\
(.0002132)\end{array}$ \\
\hline unemp & $\begin{array}{c}.0555293 * * \\
(.0200432)\end{array}$ & $\begin{array}{c}.0640859 * * \\
(.0216059)\end{array}$ & $\begin{array}{c}.0676017^{* *} \\
(.0212057)\end{array}$ & $\begin{array}{l}.0701921 * * * \\
(.0202247)\end{array}$ & $\begin{array}{l}.07574 * * * \\
(.0183014)\end{array}$ \\
\hline secondary & $\begin{array}{c}-.0301783^{* * *} \\
(.0055133)\end{array}$ & $\begin{array}{c}-.0289344 * * * \\
(.0053545)\end{array}$ & $\begin{array}{c}-.0281829 * * * \\
(.0054459)\end{array}$ & $\begin{array}{c}-.0271591^{* * *} \\
(.0055438)\end{array}$ & $\begin{array}{c}-.0234733^{* * *} \\
(.0062849)\end{array}$ \\
\hline tertiary & $\begin{array}{l}-1.17 \mathrm{E}-03 \\
(.0032731)\end{array}$ & $\begin{array}{l}-9.37 \mathrm{E}-04 \\
(.0034233)\end{array}$ & $\begin{array}{l}8.72 \mathrm{E}-05 \\
(.0035066)\end{array}$ & $\begin{array}{l}8.99 \mathrm{E}-04 \\
(.0034356)\end{array}$ & $\begin{array}{l}2.72 \mathrm{E}-03 \\
(.0031161)\end{array}$ \\
\hline p_housing & $\begin{array}{c}9.12 \mathrm{e}-07 * * * \\
(2.62 \mathrm{e}-07)\end{array}$ & $\begin{array}{c}8.85 \mathrm{e}-07 * * \\
(2.94 \mathrm{e}-07)\end{array}$ & $\begin{array}{c}9.17 \mathrm{e}-07 * * \\
(3.27 \mathrm{e}-07)\end{array}$ & $\begin{array}{c}9.06 \mathrm{e}-07 * * \\
(3.40 \mathrm{e}-07)\end{array}$ & $\begin{array}{c}9.89 \mathrm{e}-07 * * \\
(3.54 \mathrm{e}-07)\end{array}$ \\
\hline crosser & $\begin{array}{c}-.0002274 * * \\
(.0000869)\end{array}$ & $\begin{array}{l}-.0002221^{* *} \\
(.0000857)\end{array}$ & $\begin{array}{c}-.0002211^{* *} \\
(.0000851)\end{array}$ & $\begin{array}{c}-.0002201 * * \\
(.0000836)\end{array}$ & $\begin{array}{c}-.0002246 * * \\
(.000083)\end{array}$ \\
\hline dist_center & $\begin{array}{l}-9.50 \mathrm{e}-06^{* * *} \\
(1.96 \mathrm{e}-06)\end{array}$ & $\begin{array}{l}-8.86 \mathrm{e}-06^{* * *} \\
(2.01 \mathrm{e}-06)\end{array}$ & $\begin{array}{l}-9.05 \mathrm{e}-06^{* * *} \\
(2.20 \mathrm{e}-06)\end{array}$ & $\begin{array}{l}-8.99 \mathrm{e}-06 * * * \\
(2.21 \mathrm{e}-06)\end{array}$ & $\begin{array}{l}-8.40 \mathrm{e}-06^{* * *} \\
(2.10 \mathrm{e}-06)\end{array}$ \\
\hline pop & $\begin{array}{l}.0001282 * * * \\
(.0000316)\end{array}$ & $\begin{array}{l}.0001265^{* * *} \\
(.0000312)\end{array}$ & $\begin{array}{l}.000126 * * * \\
(.0000309)\end{array}$ & $\begin{array}{l}.0001256^{* * *} \\
(.0000303)\end{array}$ & $\begin{array}{l}.0001261 * * * \\
(.0000299)\end{array}$ \\
\hline pop2 & $\begin{array}{l}-3.10 \mathrm{e}-10^{* * *} \\
(8.10 \mathrm{e}-11)\end{array}$ & $\begin{array}{c}-3.05 \mathrm{e}-10 * * * \\
(7.99 \mathrm{e}-11)\end{array}$ & $\begin{array}{l}-3.04 \mathrm{e}-10 * * * \\
(7.92 \mathrm{e}-11)\end{array}$ & $\begin{array}{l}-3.02 \mathrm{e}-10 * * * \\
(7.76 \mathrm{e}-11)\end{array}$ & $\begin{array}{c}-3.04 \mathrm{e}-10^{* * *} \\
(7.63 \mathrm{e}-11)\end{array}$ \\
\hline rural & $\begin{array}{c}-.601049 * * * \\
(.0428554)\end{array}$ & $\begin{array}{c}-.5894623 * * * \\
(.0434391)\end{array}$ & $\begin{array}{c}-.5894947 * * * \\
(.0449991)\end{array}$ & $\begin{array}{c}-.5826569 * * * \\
(.0447141)\end{array}$ & $\begin{array}{l}-.5754253^{* * *} \\
(.0469632)\end{array}$ \\
\hline tourism & $\begin{array}{l}.1675803 * * * \\
(.0442906)\end{array}$ & $\begin{array}{l}.1587132 * * * \\
(.0420588)\end{array}$ & $\begin{array}{l}.1692562 * * * \\
(.0399192)\end{array}$ & $\begin{array}{c}.1700297 * * * \\
(.0385863)\end{array}$ & $\begin{array}{c}.1473164 * * * \\
(.0404714)\end{array}$ \\
\hline German & $\begin{array}{c}12.99379 * * * \\
(1.041104)\end{array}$ & $\begin{array}{c}12.48934 * * * \\
(.8898982)\end{array}$ & $\begin{array}{c}12.16493 * * * \\
(.8223827)\end{array}$ & $\begin{array}{c}11.82041 * * * \\
(.8006283)\end{array}$ & $\begin{array}{c}11.85807 * * * \\
(.9211166)\end{array}$ \\
\hline French & $\begin{array}{l}2.95 \mathrm{E}+00 \\
(1.915758)\end{array}$ & $\begin{array}{l}3.824004^{*} \\
(1.857472)\end{array}$ & $\begin{array}{c}3.665687 * \\
(1.837663)\end{array}$ & $\begin{array}{l}3.993924^{*} \\
(1.806114)\end{array}$ & $\begin{array}{l}4.00134 * \\
(1.791181)\end{array}$ \\
\hline Italian & $\begin{array}{c}7.327406 * * * \\
(.5756392)\end{array}$ & $\begin{array}{c}7.229713 * * * \\
(.5324307)\end{array}$ & $\begin{array}{c}7.271939 * * * \\
(.5368628)\end{array}$ & $\begin{array}{c}7.276574 * * * \\
(.5274229)\end{array}$ & $\begin{array}{r}7.68569 * * * \\
(.5302708)\end{array}$ \\
\hline Port & $\begin{array}{c}3.368738 * * * \\
(.5555795)\end{array}$ & $\begin{array}{l}3.418641 * * * \\
(.549568)\end{array}$ & $\begin{array}{c}3.434853 * * * \\
(.5473779)\end{array}$ & $\begin{array}{c}3.611678 * * * \\
(.5369756)\end{array}$ & $\begin{array}{r}3.59837 * * * \\
(.5496045)\end{array}$ \\
\hline Spanish & $\begin{array}{l}-7.78 E-01 \\
(5.702105)\end{array}$ & $\begin{array}{l}\text { 3.43E-01 } \\
(5.395722)\end{array}$ & $\begin{array}{l}2.51 \mathrm{E}-01 \\
(5.168726)\end{array}$ & $\begin{array}{l}\text { 2.63E-01 } \\
(4.870614)\end{array}$ & $\begin{array}{c}1.25 \mathrm{E}+00 \\
(4.59122)\end{array}$ \\
\hline UK & $\begin{array}{c}10.78383 * \\
(4.748291)\end{array}$ & $\begin{array}{c}10.68538 * \\
(4.692198)\end{array}$ & $\begin{array}{c}10.31288 * \\
(4.966951)\end{array}$ & $\begin{array}{c}10.46596 * \\
(4.762829)\end{array}$ & $\begin{array}{c}11.58351^{*} \\
(4.807654)\end{array}$ \\
\hline constant & $\begin{array}{l}2.374631 * * * \\
(.602816)\end{array}$ & $\begin{array}{c}2.788952 * * * \\
(.6168306)\end{array}$ & $\begin{array}{c}2.869278 * * * \\
(.609731)\end{array}$ & $\begin{array}{c}2.941898 * * * \\
(.5434783)\end{array}$ & $\begin{array}{c}2.521477 * * * \\
(.3909217)\end{array}$ \\
\hline lnalpha & $\begin{array}{c}-1.02905^{* * *} \\
(.1358887)\end{array}$ & $\begin{array}{c}-1.037537 * * * \\
(.1399861)\end{array}$ & $\begin{array}{l}-1.039326^{* * *} \\
(.139221)\end{array}$ & $\begin{array}{c}-1.042266^{* * *} \\
(.1363476)\end{array}$ & $\begin{array}{c}-1.038428 * * * \\
(.1300695)\end{array}$ \\
\hline log likelihood & -6101.02 & -6094.403 & -6092.755 & -6089.475 & -6088.138 \\
\hline
\end{tabular}
effects and zinb(inflate) results not shown 
Table 6: Sensitivity analysis 2: Relative impact of municipality characteristics on intranational migration, different tax rates

\begin{tabular}{lrrrrrr} 
& tax & labor & housing & crosser & urbanity & network \\
\hline ts_50000 & $5.7 \%$ & $20.9 \%$ & $6.4 \%$ & $9.3 \%$ & $38.1 \%$ & $19.6 \%$ \\
ts_80000 & $6.2 \%$ & $21.0 \%$ & $6.4 \%$ & $9.3 \%$ & $37.7 \%$ & $19.5 \%$ \\
ts_125000 & $6.3 \%$ & $21.0 \%$ & $6.4 \%$ & $9.2 \%$ & $37.7 \%$ & $19.4 \%$ \\
ts_200000 & $6.5 \%$ & $21.0 \%$ & $6.4 \%$ & $9.2 \%$ & $37.6 \%$ & $19.3 \%$ \\
ts_500000 & $6.5 \%$ & $20.8 \%$ & $6.5 \%$ & $9.2 \%$ & $37.3 \%$ & $19.6 \%$ \\
\hline
\end{tabular}

Sensitivity analysis 3:

The low weight of the tax rate could be due to the fact that only the average tax-sensitivity of all immigrants has been measured. Empirical literature suggests that the skilled people are the most tax-mobile; therefore, if most immigrants are low-skilled, then the tax coefficients would be low as well, even if the high-skilled immigrants are strongly tax-sensitive. (According to official data, 83\% of all employed foreigners who immigrated to Switzerland between 2002 and 2010 have at least a secondary education; 51\% had completed a tertiarylevel education.) However, if we wish to test whether high-skilled immigrants are more taxsensitive than less-qualified immigrants, we cannot rely on the data, as there are no municipality-level data regarding the skill levels of newly arrived immigrants. Therefore, we conduct an indirect test: it is plausible to assume that high-skilled immigrants would move to municipalities where median incomes are high, as these imply high wages and/or attractive residential locations. We split the municipalities into two groups. The first includes all the affluent municipalities with a median income that is equal to or greater than the $80^{\text {th }}$ percentile of all municipalities; the second group includes all the other municipalities. By redoing the regressions, we find that the tax-sensitivity of immigrants in both groups is identical (see Table 7). Therefore, this result proposes that the previous results are relatively robust, even if we cannot control for the skill level of the immigrants. 
Table 7: Sensitivity analysis 3: Split municipalities into wealthy $\left(\geq 80^{\text {th }}\right.$ percentile) and others

\begin{tabular}{|c|c|c|c|c|}
\hline & \multicolumn{2}{|c|}{ wealthy municipalities } & \multicolumn{2}{|c|}{ all other municipalities } \\
\hline & zinb(main) & zinb(inflate) & zinb(main) & zinb(inflate) \\
\hline ts_125000 & $\begin{array}{l}-.0518755^{* * *} \\
(.0125669)\end{array}$ & $\begin{array}{l}-.3819176^{* *} \\
(.1338695)\end{array}$ & $\begin{array}{l}-.0537722^{* * *} \\
(.0122312)\end{array}$ & $\begin{array}{l}0.009516 \\
(.0215349)\end{array}$ \\
\hline med_inc & $\begin{array}{l}-1.13 \mathrm{E}-05 \\
(6.34 \mathrm{e}-06)\end{array}$ & $\begin{array}{l}1.74 \mathrm{E}-05 \\
(.0000305)\end{array}$ & $\begin{array}{l}.0000162^{* * *} \\
(2.17 \mathrm{e}-06)\end{array}$ & $\begin{array}{l}.0000163^{* *} \\
(5.29 \mathrm{e}-06)\end{array}$ \\
\hline fte2 & $\begin{array}{l}6.70 \mathrm{E}-05 \\
(.0002255)\end{array}$ & $\begin{array}{l}-1.52 \mathrm{E}-03 \\
(.0020386)\end{array}$ & $\begin{array}{l}4.36 \mathrm{E}-04 \\
(.0002233)\end{array}$ & $\begin{array}{l}-3.82 E-04 \\
(.0003622)\end{array}$ \\
\hline fte3 & $\begin{array}{l}-5.18 \mathrm{E}-05 \\
(.0001441)\end{array}$ & $\begin{array}{l}-5.22 \mathrm{E}-04 \\
(.0033299)\end{array}$ & $\begin{array}{l}.0006756^{*} \\
(.0002929)\end{array}$ & $\begin{array}{l}-2.49 \mathrm{E}-04 \\
(.0003947)\end{array}$ \\
\hline unemp & $\begin{array}{l}-8.08 \mathrm{E}-03 \\
(.0326208)\end{array}$ & $\begin{array}{l}-3.22 \mathrm{E}-01 \\
(.1836486)\end{array}$ & $\begin{array}{l}.0821886 * * \\
(.0256735)\end{array}$ & $\begin{array}{l}-.0714205^{*} \\
(.0304281)\end{array}$ \\
\hline secondary & $\begin{array}{l}-7.70 \mathrm{E}-03 \\
(.0078015)\end{array}$ & $\begin{array}{l}9.92 \mathrm{E}-02 \\
(.0809834)\end{array}$ & $\begin{array}{l}-.0320896 * * * \\
(.0088262)\end{array}$ & $\begin{array}{l}-.0260241^{* * *} \\
(.0053058)\end{array}$ \\
\hline tertiary & $\begin{array}{l}.0172619 * \\
(.0086388)\end{array}$ & $\begin{array}{l}-8.33 E-03 \\
(.0417644)\end{array}$ & $\begin{array}{l}-7.13 E-03 \\
(.0047608)\end{array}$ & $\begin{array}{l}-.0269632 * * * \\
(.0057061)\end{array}$ \\
\hline p_housing & $\begin{array}{l}6.11 \mathrm{e}-07 * \\
(2.91 \mathrm{e}-07)\end{array}$ & $\begin{array}{l}-1.75 E-07 \\
(1.48 \mathrm{e}-06)\end{array}$ & $\begin{array}{l}5.81 \mathrm{e}-07^{*} \\
(2.54 \mathrm{e}-07)\end{array}$ & $\begin{array}{l}-5.23 \mathrm{E}-07 \\
(9.43 \mathrm{e}-07)\end{array}$ \\
\hline crosser & $\begin{array}{l}\text { 7.62E-05 } \\
(.0001371)\end{array}$ & $\begin{array}{l}-2.04 \mathrm{E}-02 \\
(.0233854)\end{array}$ & $\begin{array}{l}-.0001862 * \\
(.0000902)\end{array}$ & $\begin{array}{l}-9.06 \mathrm{E}-04 \\
(.0097676)\end{array}$ \\
\hline dist_center & $\begin{array}{l}-6.17 \mathrm{e}-06^{* * *} \\
(1.64 \mathrm{e}-06)\end{array}$ & $\begin{array}{l}-.0000551^{* *} \\
(.0000203)\end{array}$ & $\begin{array}{l}-7.09 \mathrm{e}-06^{* * *} \\
(1.83 \mathrm{e}-06)\end{array}$ & $\begin{array}{l}-4.60 \mathrm{E}-06 \\
(3.23 \mathrm{e}-06)\end{array}$ \\
\hline pop & $\begin{array}{l}.0003363^{* * *} \\
(.0000338)\end{array}$ & $\begin{array}{l}-.005821^{* * *} \\
(.0011108)\end{array}$ & $\begin{array}{l}.0001075^{* *} \\
(.0000337)\end{array}$ & $\begin{array}{l}-.0040676^{* * * *} \\
(.000413)\end{array}$ \\
\hline pop2 & $\begin{array}{l}-9.28 \mathrm{e}-09 * * * \\
(1.44 \mathrm{e}-09)\end{array}$ & $\begin{array}{l}2.12 \mathrm{e}-07 * * * \\
(3.99 \mathrm{e}-08)\end{array}$ & $\begin{array}{l}-2.55 \mathrm{e}-10^{* *} \\
(8.54 \mathrm{e}-11)\end{array}$ & $\begin{array}{l}1.08 \mathrm{e}-08^{* * *} \\
(1.01 \mathrm{e}-09)\end{array}$ \\
\hline rural & $\begin{array}{l}-.3700966 * * * \\
(.0659686)\end{array}$ & $\begin{array}{l}-9.68 E-01 \\
(.5590636)\end{array}$ & $\begin{array}{l}-.6132657 * * * \\
(.049207)\end{array}$ & $\begin{array}{l}-.7249748^{* *} \\
(.2320483)\end{array}$ \\
\hline German & $\begin{array}{l}11.89107 * * * \\
(1.621009)\end{array}$ & $\begin{array}{l}-64.65391 * \\
(26.25525)\end{array}$ & $\begin{array}{l}11.41509 * * * \\
(.5398483)\end{array}$ & $\begin{array}{l}-24.86203^{* * *} \\
(2.293077)\end{array}$ \\
\hline French & $\begin{array}{l}\text { 7.573896* } \\
(3.196097)\end{array}$ & $\begin{array}{l}1.02 E+01 \\
(13.08235)\end{array}$ & $\begin{array}{l}5.84 \mathrm{E}-01 \\
(3.409343)\end{array}$ & $\begin{array}{l}-16.37234^{* * *} \\
(1.721687)\end{array}$ \\
\hline Italian & $\begin{array}{l}6.313682 * * * \\
(1.779823)\end{array}$ & $\begin{array}{l}-2.62 E+01 \\
(19.08284)\end{array}$ & $\begin{array}{l}6.81461 * * * \\
(.6479784)\end{array}$ & $\begin{array}{l}-8.637441^{* * *} \\
(1.973451)\end{array}$ \\
\hline Port & $\begin{array}{l}2.95 E+00 \\
(2.772334)\end{array}$ & $\begin{array}{l}6.49 E+00 \\
(15.45696)\end{array}$ & $\begin{array}{l}3.284672 * * * \\
(.5826347)\end{array}$ & $\begin{array}{l}-19.56273^{* * *} \\
(4.519269)\end{array}$ \\
\hline Spanish & $\begin{array}{l}8.44 \mathrm{E}+00 \\
(5.512883)\end{array}$ & $\begin{array}{l}1.10 \mathrm{E}+02 \\
(82.58796)\end{array}$ & $\begin{array}{l}-4.31 \mathrm{E}-02 \\
(8.166706)\end{array}$ & $\begin{array}{l}-5.27 \mathrm{E}+00 \\
(6.714799)\end{array}$ \\
\hline UK & $\begin{array}{l}5.744829 * \\
(2.778454)\end{array}$ & $\begin{array}{l}-4.20 E+01 \\
(21.80514)\end{array}$ & $\begin{array}{l}28.11867 * * * \\
(2.66988)\end{array}$ & $\begin{array}{c}-1.53 E+01 \\
(18.87822)\end{array}$ \\
\hline tourism & & & $\begin{array}{l}.2410864 * * * \\
(.046547)\end{array}$ & $\begin{array}{l}-1.80 \mathrm{E}-01 \\
(.1517128)\end{array}$ \\
\hline constant & $\begin{array}{l}1.799796 * \\
(.7594838) \\
\end{array}$ & $\begin{array}{l}5.24 \mathrm{E}+00 \\
(4.866496) \\
\end{array}$ & $\begin{array}{l}2.486625 * * * \\
(.6418298) \\
\end{array}$ & $\begin{array}{l}4.56456^{* * *} \\
(.6527703) \\
\end{array}$ \\
\hline lnalpha & $\begin{array}{l}-2.42148 * * * \\
(.2646151)\end{array}$ & & $\begin{array}{l}-1.012971 * * * \\
(.1330628)\end{array}$ & \\
\hline log likelihood & -126 & 708 & -46 & .247 \\
\hline
\end{tabular}




\section{Conclusion}

According to theory, income taxes influence incentives to migrate in two ways. First, the decision to migrate is driven by net wage differentials between the home and host countries. As income taxes drive a wedge between gross and net wages, they can become implicitly relevant. Secondly, according to public finance theory, mobility occurs among well-informed households who try to maximize their utility by migrating to the community that offers the best service-tax package. Most empirical studies conclude that regional tax burden negatively impacts the choice of residence; however, to date, there has been great uncertainty on the relative relevance of taxes, compared to other factors.

This study has sought to rectify this lack of certitude by investigating whether immigrants, once they have decided to migrate into Switzerland, prefer to settle in municipalities with low income-tax burden. The results from cluster-specific (fixed-effects) count data regression show that taxes are a significant but weak factor in making migration decisions; its relative impact compared to other locational factors is rather low. Especially the urbanity indicators of municipalities, labor-market characteristics, and network effects are by far the most important factors to influence choice of destination municipality. This result holds for both intra- and international migration. 


\section{References}

Azen, Razia and Nicole Traxel (2009). "Using Dominance Analysis to Determine Predictor Importance in Logistic Regression." Journal of Educational and Behavioral Statistics. 34: $319-347$

Bessey, Donata (2007). “International Student Migration to Germany”. Swiss Leading House Working Paper No. 6.

Börsch-Supan, Axel (1990). "Education and its Double-Edged Impact on Mobility." Economics of Education Review. 9(1): 39-53.

Bring, Johan (1994). "How to Standardize Regression Coefficients.” The American Statistician. 48(3): 209-213.

Brülhart, Marius, Mario Jametti, and Kurt Schmidheiny (2012). "Do Agglomeration Economies Reduce the Sensitivity of Firm Location to Tax Differentials?” The Economic Journal. DOI: 10.1111/j.1468-0297.2012.02511.x

Budescu, David V. (1993). "Dominance analysis: A new approach to the problem of relative importance of predictors in multiple regression.” Psychological Bulletin. 114(3): 542551.

Dowding, Keith, Peter John, and Stephen Biggs (1994). "Tiebout: A Survey of the Empirical Literature.” Urban Studies. 31(4-5): 767-797.

Egger, Peter and Doina Maria Radulescu (2009). "The Influence of Labour Taxes on the Migration of Skilled Workers.” The World Economy. 32(9): 1365-1379.

Eugster, Beatrix and Raphaël Parchet (2013). "Culture and Taxes: Towards Identifying Tax Competition.” Mimeo, University of Lausanne.

Feld, Lars and Gebhard Kirchgässner (2001). "Income Tax Competition at the State and Local Level in Switzerland.” Regional Science and Urban Economics. 31(2-3): 181-213.

Flowerdew, Robin and Murray Aitkin (1982). “A Method of Fitting the Gravity Model based on the Poisson Distribution”. Journal of Regional Science. 22(2): 191-202.

Geis Wido, Silke Uebelmesser und Martin Werding (2008). "How do Migrants Choose their Destination Country? An Analysis of Institutional Determinants." CESifo Working Paper No. 2506.

Guimarães, Paulo, Douglas Woodward, and Octávio Figueiredo (2003). "A Tractable Approach to the Firm Location Decision Problem.” Review of Economics and Statistics. 84: 201-204.

Hatton, Timothy J. and Jeffrey G. Williamson (2002). "What Fundamentals Drive World Migration?” NBER Working Paper No. 9159.

Haug, Sonia (2008). "Migration Networks and Migration Decision-Making.” Journal of Ethnic and Migration Studies. 34(4): 585-605.

Hicks, John R. (1932). The Theory of Wages. New York: Macmillan. 
Kirchgässner, Gebhard and Werner W. Pommerehne (1996). "Tax Harmonization and Tax Competition in the European Union: Lessons from Switzerland.” Journal of Public Economics. 60(3): 351-371.

Kleven, Henrik, Camille Landais and Emmanuel Saez (2010). "Taxation and International Migration of Superstars: Evidence from the European Football Market.” NBER Working Paper No. 16545.

Kleven, Henrik J., Camille Landais, Emmanuel Saez, and Esben Schultz (2011). "Taxation and International Migration of Top Earners: Evidence from the Foreigner Tax Scheme in Denmark.” Mimeo.

Liebig, Thomas und Alfonso Sousa-Poza (2006). "The Influence of Taxes on Migration: Evidence from Switzerland.” Cambridge Journal of Economics. 30: 235-252.

Liebig, Thomas, Patrick A. Puhani, and Alfonso Sousa-Poza (2007). “Taxation and Internal Migration - Evidence from the Swiss Census Using Community-Level Variation in Income Tax Rates.” Journal of Regional Science, 47(4): 807-836.

Lovett, Andrew, I. D. Whyte, and K.A. Whyte (1985). "Poisson Regression Analysis and Migration Fields: The Example of the Apprenticeship Records of Edinburgh in the Seventeenth and Eighteenth Centuries.” Transactions of the Institute of British Geographers New Series. 10(3): 317-332.

McFadden, Daniel (1973). “Conditional Logit Analysis of Qualitative Choice Behavior.” In: Frontiers in Econometrics (ed. P. Zarembka), 105-42. New York: Academic Press.

Nowotny, Klaus (2011). "Welfare Magnets, Taxation and the Location Decisions of Migrants to the EU.” WIFO Working Papers No. 393/2011.

Pedersen, Peder J., Mariola Pytlikova, and Nina Smith (2008). "Selection and Network Effects -Migration Flows into OECD countries 1990-2000.” European Economic Review. 52(7): 1160-1186.

Pirttilä, Jukka (2004). "Is International Labour Mobility a Threat to the Welfare State? Evidence from Finland in the 1990s.” Finish Economic Papers. 17(1): 18-34.

Pisati, Maurizio (2007). "SPMAP: Stata Module to Visualize Spatial Data.” Statistical Software Components S456812, Boston College Department of Economics, revised 14 Mar 2008.

Schaltegger, Christoph A., Frank Somogyi und Jan-Egbert Sturm (2011). „Tax Competition and Income Sorting: Evidence from the Zurich Metropolitan Area. European Journal of Political Economy. 27(3): 455-470.

Schmidheiny, Kurt (2006). "Income Segregation and Local Progressive Taxation: Empirical Evidence from Switzerland.” Journal of Public Economics. 90: 429-458.

Shen Jianfa (1999). "Modelling Regional Migration in China: Estimation and Decomposition.” Environment and Planning A. (31): 1223-1238.

Tiebout, Charles M. (1956). “A Pure Theory of Local Expenditures.” Journal of Political Economy. 64(5): 416-424. 
Vuong, Quang H. (1989). "Likelihood Ratio Tests for Model Selection and Non-Nested Hypothesises.” Econometrica. 57(2): 307-333.

Wagner, Don (2000). “Do Tax Differences Cause the Brain Drain?” Policy Options, December, 33-41.

Welch, B. L. (1947). "The Generalization of 'Student's' Problem when Several Different Population Variances are Involved". Biometrika 34 (1-2): 28-35.

Wooldridge, Jeffrey M. (1999). "Distribution-free Estimation of Some Nonlinear Panel Data Models.” Journal of Econometrics (90): 77-97.

Wooldridge, Jeffrey M. (2006). "Cluster-sample Methods in Applied Econometrics: An Extended Analysis.” Mimeo.

Wüest and Partner (2011). “Immo-Monitoring 2011 / 2 - Frühlingsausgabe”, Zurich.

Zavodny, Madeline (1999). “Determinants of Recent Immigrants' Locational Choice.” International Migration Review. 33(4): 1014-1030. 